\title{
PENYELESAIAN TINDAK PIDANA KEKERASAN DALAM RUMAH TANGGA MELALUI MEDIASI PENAL DIHUBUNGKAN DENGAN KEADILAN RESTORATIF (Studi Kasus di Kota Pekanbaru)
}

\author{
Santy \\ Dosen Fakultas Hukum STMIK Dharmapala Riau \\ J1. Kh Samanhudi No.13, Sago, Kec. Senapelan, Kota Pekanbaru, Riau 28155 \\ Email : santytie@yahoo.co.id
}

\begin{abstract}
RINGKASAN
Penyelesaian kasus kekerasan rumah tangga idealnya mencari alternatif yang memulihkan keadaan seperti semula tetapi realitas sosial menunjukkan tingkat keberhasilan mediasi penal masih cukup rendah sehingga harapan atas keadilan restorative justice untuk menjaga keharmonisan rumah tangga belum tercapai. Penelitian ini bertujuan untuk mendeskripsikan penyelesaian perkara KDRT melalui mediasi penal dihubungkan dengan keadilan restoratif dan menentukan akibat hukum atas kesepakatan damai yang dihasilkan mediasi penal terhadap penyidikan tindak pidana KDRT di Kota Pekanbaru. Penelitian ini menggunakan pendekatan hukum normatif. Spesifikasi penelitian deskriptif analisis, jenis data sekunder, teknik pengumpulan data studi dokumentasi dengan menggunakan teknik analisis kualitatif. Hasil penelitian menunjukan (1) Tindak pidana KDRT di Kota Pekanbaru secara faktual cenderung diselesaikan secara formal (litigasi) diikuti dengan permohonan perceraian disebabkan upaya mediasi penal belum menunjukkan usaha dan hasil yang memadai karena secara empiris ditemukan beberapa persoalan mendasar, yaitu (a) masalah operasional (lemahnya komunikasi penegak hukum dengan para pihak, keterbatasan waktu, tindak lanjut hasil medasi) (b) kualitas (kompetensi) penegak hukum (c) masalah kepatuhan pelaku untuk menjalankan kesepakatan mediasi terbukti dengan adanya pengulangan tindak kekerasan kepada korban (2) Kesepakatan perdamaian antara pelaku dengan korban dan keluarganya sebagai hasil proses mediasi penal menimbulkan akibat hukum terhadap proses penegakan hukum berupa penghentian proses penyidikan tindak pidana kekerasan dalam rumah tangga yang sedang berjalan di Kota Pekanbaru karena akta perdamaian yang disepakati para pihak merupakan produk hukum yang memiliki kekuatan hukum mengikat untuk dihormati dan dijalankan para pihak supaya memberikan kepastian hukum bagi status perkara di masa mendatang. Penghentian penyidikan merupakan kebijakan diskresi penegak hukum di Kota Pekanbaru dengan syarat apabila pelaku mengingkari kesepakatan damai dengan mengulangi tindak pidana kekerasan maka langsung diproses secara formal (pengadilan).
\end{abstract}

Kata Kunci : Kekerasan Dalam Rumah Tangga, Mediasi Penal, Keadilan Restoratif

\section{PENDAHULUAN}

Bentuk kekerasan yang banyak terjadi saat ini adalah kekerasan yang dilakukan dalam lingkup keluarga atau kekerasan dalam rumah tangga di berbagai wilayah di Indonesia. Saat ini kasus-kasus kekerasan dalam rumah tangga banyak terjadi di kalangan masyarakat bawah hingga mereka yang memiliki status sosial dan pendidikan tinggi. Kebanyakan korban kekerasan dalam rumah tangga adalah dari kaum hawa/wanita di mana mereka mengalami kekerasan fisik sampai menimbulkan dampak traumatis mendalam pada korban. Akibat dari kekerasan itu banyak sekali korban ibu rumah tangga yang mengalami gangguan trauma sehingga harus mendapatkan perawatan dari aparat penegak hukum dan pemerintah daerah setempat.

Kasus kekerasan dalam rumah tangga memerlukan penyelesaian secara humanis mengingat penderitaan 
mental/jiwa yang diderita oleh korban cukup berat. Namun dalam pelaksanaan perlindungannya korban masih menimbulkan berbagai persoalan seperti penempatan, perawatan, pengobatan, terapi dan lainlain. Oleh karena itu, memerlukan adanya penanggulangan yang cepat dari pemerintah daerah setempat melalui aparat penegak hukum. adanya Undangundang No 23 Tahun 2004 tentang Penghapusan Kekerasan Dalam Rumah Tangga diharapkan dapat menjadi solusi untuk mencegah dan menanggulangi tindak kekerasan dalam rumah tangga sesuai dengan asas yang diatur dalam Pasal 3 yang menyatakan bahwa UndangUndang penghapusan kekerasan dalam rumah tangga berlandaskan asas.

kekerasan dalam rumah tangga yang lebih banyak lagi. Beberapa kota besar seperti Jakarta, Bandung, Semarang, Surabaya dan Medan merupakan wilayah yang memiliki rutinitas yang sangat padat sehingga membuat para sumber daya menusia di daerah tersebut harus cukup keras dalam menjalankan aktivitas bisnis, kondisi ini merupakan salah satu faktor pemicu seorang pria/wanita mengalami stress dan menimbulkan perilaku agresif pada isterinya atau pada anaknya, dan menjadi faktor pemicu tindak kekerasan dalam rumah tangga. Kenyataan ini menjadi gambaran bahwa faktor yang mendorong terjadinya kejahatan adalah faktor lingkungan yang mempengaruhi perilaku individu masyarakat. Aktivitas yang padat dan rasa stress yang tinggi memudahkan seseorang untuk berlaku keras dan memicu terjadinya kekerasan pada orang lain termasuk pada orang terdekat sekalipun.

Kasus Kekerasan Dalam Rumah Tangga (KDRT) menurut Komnas Perempuan masuk dalam ranah personal dimana pelakunya adalah suami, isteri, ayah, ibu, anak dan pembantu rumah tangga atau orang-orang yang berada dalam lingkungan keluarga. KDRT terjadi karena adanya perbedaan pandangan dalam menyikapi persoalan dalam lingkungan keluarga yang memicu terjadinya kekerasan baik dalam bentuk fisik, psikis, maupun seksual. Angka KDRT dalam beberapa tahun terakhir mengalami fluktuasi karena langkah-langkah yang dilakukan oleh lembaga-lembaga negara untuk menanggulangi kejahatan ini cukup masif.

Kekerasan dalam rumah tangga (KDRT) secra nasional penyebabnya banyak faktor. Pertama, kombinasi dari banyak persoalan, seperti faktor ekonomi, sosial, anak, dan lain sebagainya. Kedua, ekonomi. Ketiga, pendidikan dan iman. Faktor dominan yang menjadi penyebab KDRT ialah ekonomi. Dalam masalah ini, setidaknya terbagi dua kelompok yang menjadi pelaku dan korban KDRT. Pertama, mereka sudah mapan ekonominya. Kedua, masyarakat miskin. Mereka yang sudah mapan ekonominya, bisa melakukan KDRT. Penyebabnya bisa berbagai macam seperti sudah mempunyai pacar atau isteri simpanan. Selain itu, suami-isteri sibuk, anak kemudian tidak mendapat perhatian, sehingga terlibat bergaulan bebas serta narkoba. Akibatnya, suami melakukan KDRT ke isteri sebagai pelampiasan kekesalan. Pada masyarakat bawah, KDRT dilakukan pada umumnya karena kesulitan ekonomi. Suami atau isteri melakukan KDRT untuk melampiaskan depresi atau stres akibat tekanan ekonomi. Kekerasan rumah tangga karena tekanan ekonomi, banyak yang berujung dengan kematian. Bapak membunuh anak dan isteri dan sebagainya.

Data KDRT pada tingkat nasional yang jumlahnya mencapai ribuan kasus tidak lepas dari berbagai 
kasus yang terjadi di banyak daerah. Lemahnya kesadaran masyarakat atas kerukunan berumah tangga menjadi salah satu penyebab terjadinya kekerasan dalam lingkungan keluarga. Angka kekerasan di daerah menjadi penyumbang tingginya angka kekerasan di tingkat nasional. Untuk tingkat daerah, angka KDRT menurut data Polresta Pekanbaru angkanya masih cukup tinggi seperti terlihat pada tabel di bawah ini:

\begin{tabular}{|l|l|l|l|l|}
\hline $\begin{array}{c}\text { N } \\
\text { o }\end{array}$ & $\begin{array}{l}\text { Tah } \\
\text { un }\end{array}$ & $\begin{array}{c}\text { Juml } \\
\text { ah } \\
\text { Kasu } \\
\text { s }\end{array}$ & $\begin{array}{c}\text { Penyeles } \\
\text { aian } \\
\text { Kasus }\end{array}$ & $\begin{array}{c}\text { Penyeles } \\
\text { aian } \\
\text { Mediasi }\end{array}$ \\
\hline 1 & $\begin{array}{l}201 \\
5\end{array}$ & 75 & 37 & 20 \\
\hline 2 & $\begin{array}{l}201 \\
6\end{array}$ & 84 & 68 & 16 \\
\hline 3 & $\begin{array}{l}201 \\
7\end{array}$ & 67 & 46 & 21 \\
\hline
\end{tabular}

Sumber : Satreskrim Uni PPA Polresta

Pekanbaru, Tahun 2015-2017

$$
\text { Rekapitulasi data Satuan }
$$

Reskrim Polresta Pekanbaru di atas menunjukan sebuah kenyataan sosial bahwa angka tindak pidana KDRT di wilayah kota Pekanbaru masih cukup tinggi. Korban KDRT lebih banyak didominasi oleh perempuan dan anak. Bentuk kekerasan yang dilakukan adalah dalam bentuk fisik seperti memukul, menendang, menampar dan kekerasan fisik lainnya, sedangkan bentuk kekerasan psikis berupa bentakan yang menimbulkan ketakutan, mengucapkan kalimat yang tidak pantas dan sebagainya.

Bentuk kekerasan fisik maupun psikis pelaku terhadap korban secara langsung menimbulkan dampak yang tidak baik dalam melangsungkan kehidupan rumah tangga. Pasca terjadinya kekerasan biasanya hubungan pelaku dan korban menjadi tidak harmonis dan tidak saling memenuhi kewajiban masing-masing. Efek KDRT bagi masyarakat Kota Pekanbaru menimbulkan efek negatif bagi kehidupan rumah tangga dan sosial.

Berdasarkan data KDRT 2015-2017 ditemukan beberapa sebab pemicu terjadinya kekerasan antara lain faktor ekonomi yang tidak tercukupi, layanan seksual, emosional dan relasi kekuasaan. Laporan kasus dalam 3 (tiga) tahun terakhir (2015-2017) faktor ekonomi selalu menjadi penyebab retaknya hubungan rumah tangga dan berakhir pada tindak kekerasan. Persoalan penyelesaian KDRT di Kota Pekanbaru juga menjadi perhatian masyarakat karena masih tingginya kecenderungan para pihak dan aparat penegak hukum untuk menyelesaikan secara formal-yudisial (pengadilan). Padahal sejatinya urusan KDRT bukan semata-mata untuk mencari kesalahan salah satu pihak dan memberikan sanksi pidana karena model penyelesaian itu akan semakin memperburuk keadaan dan merusak hubungan kekeluargaan yang terjalin antara para pihak. Persoalan penyelesaian KDRT di Kota Pekanbaru merujuk pada data tersebut memerlukan kesadaran hukum bahwa penyelesaian secara mediasi pada hakikatnya lebih menjanjikan keharmonisan dan mengedepankan keutuhan rumah tangga yang sudah dijalin oleh para pihak

Penyelesaian KDRT di Kota Pekanbaru secara litigasi secara empiris tidak menyentuh akar persoalan yang terjadi dalam rumah tangga para pihak menyebabkan terjadinya perceraian dan anak yang broken home menjadi faktor kriminogen timbulnya kejahatankejahatan yang dilakukan anak di Kota Pekanbaru. Penyelesaian KDRT di Kota Pekanbaru merupakan masalah hukum tetapi memiliki dampak sosial yang cukup luas bagi keamanan dan ketertiban masyarakat Kota Pekanbaru elama ini perlakuan yang tidak 
manusiawi dalam kasus KDRT di Pekanbaru dilaporkan secara langsung oleh korban ke polisi yang mengakibatkan pelaku diadili melalui proses litigasi dan akhirnya mereka bercerai, sedangkan korban diserahkan kepada Dinas Sosial Kota Pekanbaru untuk memperoleh pembinaan dan pendalaman agama, mental, serta menjadi mandiri melalui pelatihan usaha ekonomi produktif.

Penyelesaian perkara pidana jika menempuh jalur penal biasanya selalu adanya penjatuhan pidana oleh hakim terhadap pelaku, secara empiris terkadang tidak memuaskan semua pihak, oleh karena itu perlu adanya pemikiran penyelesaian perkara pidana.

Menurut Muladi model konsensus yang dianggap menimbulkan konflik baru harus diganti dengan model asensus, karena dialog antara yang berselisih untuk menyelesaikan masalahnya, adalah langkah yang sangat positif. Dengan konsep ini muncul istilah ADR yang dalam hal-hal tertentu lebih memenuhi tuntutan keadilan dan efesien. ADR ini merupakan bagian dari konsep restorative justice yang melibatkan seorang mediator.

\section{Permasalahan}

Bagaimana Penyelesaian Tindak Pidana Kekerasan Dalam Rumah Tangga Melalui Mediasi Penal Dihubungkan Dengan Keadilan Restoratif (Studi Kasus Di Kota Pekanbaru)

\section{Tinjauan Teoritis}

Menurut Mansour Fakih (1997), kekerasan" pada umumnya dipahami hanya menyangkut kekerasan fisik belaka. Kekerasan juga dapat diartikan sebagai tindakan yang membawa kekuatan untuk melakukan paksaan ataupun tekanan berupa fisik maupun non fisik atau dapat juga diartikan sebagai serangan.

Menurut

Harkristuti

Harkrisnowo (2000), kekerasan terhadap perempuan tidak mendapatkan perhatian yang memadai dalam sistem hukum termasuk aparat hukum dan budaya hukum yang ada dalam masyarakat Indonesia karena pemaknaan kekerasan atau persepsi mengenai tindak kekerasan yang ada dalam masyarakat.

Menurut Kandati (2013), Ruang lingkup kekerasan dalam rumah tanggan merujuk :

a. Kekerasan fisik adalah suatu tindakan kekerasan (seperti: memukul, menendang, dan lainlain) yang mengakibatkan luka, rasa sakit, atau cacat pada tubuh istri hingga menyebabkan kematian. Kekerasan fisik dilakukan dengan menggunakan kekuatan fisik dan menimbulkan luka fisik. Jenis kekerasan ini paling mudah untuk diidentifikasi dan ditemukan untuk menungkap adanya tindak kekerasan dalam rumah tangga.

b. Kekerasan psikis adalah suatu tindakan penyiksaan secara verbal (seperti: menghina, berkata kasar dan kotor) yang mengakibatkan menurunnya rasa percaya diri, meningkatkan rasa takut, hilangnya kemampuan untuk bertindak dan tidak berdaya. Kekerasan psikis ini apabila sering terjadi maka dapat mengakibatkan korban semakin tergantung pada pelaku meskipun suaminya telah membuatnya menderita. Di sisi lain kekerasan psikis juga dapat memicu dendam dihati istri. Kekerasan psikis berbeda dengan fisik bentuk kekerasan ini tidak terlihat secara nyata tetapi akibatnya mampu 
memberikan penderitaan yang luar biasa kepada korban.

c. Kekerasan seksual adalah suatu perbuatan yang berhubungan dengan memaksa istri untuk melakukan hubungan seksual dengan cara-cara yang tidak wajar atau bahkan tidak memenuhi kebutuhan seksual istri. Kekerasan seksual biasanya dilakukan oleh suami untuk memenuhi hasrat kebutuhan seksualnya dengan cara memaksa, mengintimidasi isteri untuk meladeni kebutuhan biologisnya. Suami kadangkala tidak melihat dan memahami kondisi isteri apakah mampu untuk melayani suami atau tidak secara fisik. Pada hakikatnya seorang isteri wajib mematuhi segala perintah suaminya tetapi keadaan tersebut tidak bersifat mutlak karena seorang suami seharusnya mengerti dan memahami keadaan atau kondisi sang isteri. Misalnya ketika isteri sedang sakit semestinya suami tidak memaksakan kehendak agar isteri mau meladeninya karena jika dipaksakan dikhawatirkan akan memperparah kondisi kesehatan isteri.

d. Kekerasan ekonomi adalah suatu tindakan yang membatasi istri untuk bekerja di dalam atau di luar rumah untuk menghasilkan uang dan barang, termasuk membiarkan istri yang bekerja untuk dieksploitasi, sementara suami tidak memenuhi kebutuhan ekonomi keluarga. Sebagian suami juga tidak memberikan gajinya pada istri karena istrinya berpenghasilan, suami menyembunyikan gajinya, mengambil harta istri, tidak memberi uang belanja yang mencukupi, atau tidak memberi uang belanja sama sekali, menuntut istri memperoleh penghasilan lebih banyak, dan tidak mengijinkan istri untuk meningkatkan karirnya. Kekerasan ekonomi berkaitan erat dengan masalah sandang, pangan dan papan yang menjadi kebutuhan pokok dalam membangun rumah tangga. Kebutuhan ekonomi menjadi faktor penunjang utama untuk menjalani kehidupan, menjalani rumah tangga tanpa ditunjang dengan pemenuhan ekonomi akan memicu ketidakharmonisan rumah tangga

e. Bentuk kekerasan ini berkaitan dengan pelaksanaan kewajiban para pihak dalam menjalani kehidupan rumah tangga. Seorang suami sudah seharusnya memberikan nafkah lahir batin kepada anak dan isterinya. Nafkah bukan hanya dalam bentuk materi tetapi juga dalam bentuk perhatian dan kasih sayang. Sebaliknya seorang isteri berkewajiban melaksanakan tanggung jawabnya untuk meladeni suami seperti hubungan seksual, komunikasi dengan baik, menyiapkan makanan, pakaian dan lain-lain. Korban penelantaran rumah tangga bukan hanya suami atau isteri tetapi juga anak, seorang anak yang tidak memperoleh perhatian, kasih sayang dari kedua orang tuanya bisa dikatakan mengalami kekerasan rumah tangga dalam bentuk penelantaran sehingga anak menjadi broken home dan cenderung bergaul ke arah hal-hal yang negatif.

UU No. 30/1999, Mediasi penal merupakan salah satu bentuk alternatif penyelesaian sengketa di luar pengadilan yang biasa dikenal dengan istilah ADR atau "Alternative Dispute Resolution"; ada pula yang menyebutnya "Apropriate Dispute Resolution". 
PEMBAHASAN

\section{Penyelesaian Tindak Pidana \\ Kekerasan Dalam Rumah Tangga (KDRT) Melalui Mediasi Penal di Kota Pekanbaru Dihubungkan Dengan Keadilan Restoratif}

Secara institusional penyelesaian KDRT di wilayah hukum Polresta Pekanbaru melalui mediasi penal dapat dilaksanakan apabila memenuhi syarat formal sebagaimana ditentukan dalam Surat Edaran Polri No 8/VII/2018 tentang Penerapan Keadilan Restoratif Dalam Penyelesaian Perkara Pidana, yaitu

1. Adanya permohonan perdamaian kedua belah pihak (pelapor dan terlapor)

2. Surat pernyataan perdamaian (akte dading) dan penyelesaian perselisihan para pihak yang berperkara (pelapor, terlapor, keluarga, perwakilan dari tokoh masyarakat diketahui oleh atasan penyidik.

3. Berita Acara Pemeriksaan Tambahan pihak yang berperkara setelah dilakukan penyelesaian keadilan restoratif

4. Rekomendasi gelar perkara khusus yang menyetujui penyelesaian keadilan restoratif 5. Pelaku tidak keberatan atas tanggung jawab ganti rugi, atau dilakukan dengan sukarela 6 . Keadilan restoratif dapat diterapkan terhadap kejahatan umum yang tidak menimbulkan korban manusia.

Penyelesaian KDRT di pekanbaru apabila telah memenuhi syarat formil di atas dapat diselesaikan secara restoratif dengan melaksanakan mekanisme sebagai berikut :

a. Penyidik telah menerima permohonan perdamaian kedua belah pihak (pelapor dan terlapor) yang ditandatangani di atas materai b. Permohonan diajukan kepada atasan penyidik untuk mendapat persetujuan

c. Setelah permohonan disetujui oleh atasan penyidik (Kabareskrim Polresta Pekanbaru) kemudian ditetapkan waktu pelaksanaan penandatanganan pernyataan perdamaian

d. Pelaksanaan konferensi yang menghasilkan perjanjian kesepakatan yang ditandatangani semua pihak yang terlibat

e. Membuat nota dinas kepada pengawas penyidik perihal permohonan dilaksanakan gelar perkara khusus untuk tujuan penghentian penyidikan perkara

f. Melaksanakan gelar perkara khusus dengan peserta pelapor, dan/atau keluarga pelapor, terlapor dan/atau keluarga terlapor dan perwakilan dari tokoh masyarakat yang ditunjuk oleh penyidik

g. Menyusun kelengkapan administrasi dan dokumen gelar perkara khusus serta laporan hasil gelar perkara

h. Menerbitkan Surat Perintah Penghentian Penyidikan dan Surat Ketetapan Penghentian Penyidikan dengan alasan restorative justice.

i. Mencatat dalam buku register baru B-19 sebagai perkara keadilan restoratif dihitung sebagai penyelesaian perkara.

Mediasi penal menjadi salah satu pilihan yang dijalankan untuk menyelesaikan kasus KDRT di Kota Pekanbaru. Laporan mengenai adanya dugaan KDRT pertama kali masuk ke Kantor Kepolisian di tingkat polsek. Persoalan yang terjadi kondisi yang ada di tingkat Polsek tidak memadai untuk mengadakan mediasi penal baik dari segi kualitas SDM (aparatur penegak hukum) maupun ketersediaan sarana yang menunjang aktivitas tersebut 
sehingga setiap ada laporan KDRT di tingkat Polsek cenderung selalu dilimpahkan ke tingkat Polresta Pekanbaru oleh karena disebabkan SDM dan sarana yang ada di tingkat polresta dipandang memadai untuk mengadakan mediasi penal. Persoalan ini secara teknis memperlambat proses penyelesaian karena pelimpahan kasus dari Polres menuju Polresta memakan waktu sementara korban setiap hari harus tinggal satu atap dengan pelaku yang berpotensi melakukan tindakantindakan yang merugikan korban.

Keterbatasan SDM penegak hukum dan sarana di tingkat polsek wilayah hukum Polresta Pekanbaru sudah seharusnya direspon cepat oleh para pemimpin di lingkungan kepolisian karena menyangkut masalah keamanan dan keselamatan korban. Kecepatan dan ketetapan mengumpulkan, merundingkan dan mendamaikan kedua belah pihak yang sedang berkonflik jauh lebih memberikan manfaat ketimbang mengedepankan prosedur penyelesaian kasus yang akan mengabaikan subtansi persoalan.

Persoalan penyelesaian kekerasan dalam rumah tangga di Kota Pekanbaru merujuk pada gambaran tersebut membutuhkan budaya hukum (legal culture) kesadaran hukum bahwa kecepatan dan ketepatan dalam penyelesaian secara mediasi lebih memberikan harapan untuk mempertahankan keharmonisan dan mengutamakan keutuhan rumah tangga yang sudah dijalin oleh para pihak. Kondisi kekurangan SDM maupun fasilitas pendukung mediasi penal di unit polsek membutuhkan perhatian khusus dari pihak kepolisian karena menyangkut masalah tanggung jawab profesi yang menuntut kejelian dan responsif menangkap masalah yang ada di lapangan. Ide keadilan dan perlindungan korban dalam penghapusan kekerasan KDRT di Kota Pekanbaru hanya menjadi ide abstrak yang tidak terwujud apabila tidak didukung dengan kualitas keahlian para penegak hukum yang bertugas di kantor polsek karena Polsek merupakan unit terbawah dari organisasi Kepolisian yang berhadapan langsung dengan masyarakat (pelaku/korban).

Berkaca dari persoalan di atas, penempatan personel kepolisian yang memiliki keahlian khusus sebagai mediator dan perbaikan atau kelengkapan sarana di tingkat Polsek mutlak diperlukan untuk menunjang daya kerja penegak hukum dalam meminimalisasi dan menekan angka KDRT yang masuk ke pengadilan. Dengan adanya penempatan dan perbaikan sarana di kantor polsek dapat membantu proses mediasi oleh aparat penegak hukum di tingkat polres. Dengan kata lain peningkatan peran personel di kantor Polsek untuk melakukan mediasi akan membantu mengurangi beban kerja polresta dalam menangani KDRT.

Penempatan personel yang memiliki keahlian sebagai mediator di unit polsek dipandang urgen karena setiap kasus KDRT di Kota Pekanbaru ada kecenderungan korban untuk menyelesaikan secara hukum melalui pengadilan diikuti dengan permohonan perceraian kepada pengadilan agama. Secara realitas kasus kekerasan membawa kehancuran dan perpecahan rumah tangga di Kota Pekanbaru. Keadaan ini diakui oleh Dinas Sosial Kota Pekanbaru yang banyak membina para korban KDRT setelah mereka bercerai dari suaminya yang menjadi terpidana.

Padahal semestinya ada solusi lain yang dapat menjadi wadah penyelesaian konflik KDRT antara korban dan pelaku untuk berupaya menyelamatkan kehidupan rumah tangganya. Fakta 
menunjukan berdasarkan laporan dari Pusat Pelayanan Terpadu Pemberdayaan Perlindungan Perempuan dan Anak (P2TP2A) Riau anak-anak yang menjadi korban perceraian suami dan isteri dalam kasus KDRT yang terjadi di Kota Pekanbaru menjadi broken home pergaulannya tidak terkendali dan berpotensi menjadi pelaku tindak pidana yang meresahkan masyarakat.280 Atas dasar itu resopnsivitas penegak hukum yang bertugas di polsek sangat diperlukan untuk mengantisipasi perpecahan tersebut.

Berangkat dari uraian di atas mediasi penal menjadi salah satu metode yang cukup baik untuk diterapkan agar prosentase penyelesaian kasus melalui pengadilan dapat ditekan dan diminimalisasi oleh sehingga memungkinkan menyelamatkan keutuhan rumah tangga para pihak yang terancam pecah karena adanya kekerasan

Mediasi penal merupakan salah satu instrumen untuk mencapai konsep keadilan restoratif. Para pihak yang menentukan nilai keadilan yang mereka inginkan, bukan lembaga peradilan.281 Mediasi penal merupakan metode penyelesaian sengketa yang cocok dalam menangani perkara kekerasan rumah tangga di Indonesia. Mayoritas masyarakat masih mengutamakan penyelesaian secara damai dalam penyelesaian sengketa terutama dalam sengketa keluarga dikarenakan harmoni dan keutuhan keluarga merupakan prioritas dalam budaya masyarakat Indonesia yang terus dijaga.

Model ini dalam teori disebut dengan victim offender oriented (Vom), suatu model penyelesaian perkara pidana secara win-win solution dengan melibatkan para pihak yang berkaitan dengan tindak pidana. Namun dari sekian banyak kelebihan mediasi penal, metode ini juga mempunyai beberapa kelemahan, seperti kurangnya tindak lanjut pelaku terhadap kesepakatan yang telah dibuat, penundaan persidangan perbuatan kriminal yang telah dilakukan dan putusannya karena proses mediasi penal, banyaknya waktu yang dibutuhkan untuk berpartisipasi dalam proses mediasi penal (apabila menggunakan shuttle mediation). Kendala yang pada umumnya menjadi masalah penanganan KDRT melalui mediasi penal di Kota Pekanbaru antara lain :

1) Belum melembaganya proses penyelesaian melalui mediasi ini di kalangan penegak hukum dan masyarakat.

2) Tidak adanya dasar hukum yang kuat dalam penyelesaian melalui mediasi ini menimbulkan aparat penegak hukum tidak berani melakukan diskresi.

3) Bagi pihak korban khususnya seorang isteri terkadang tidak mau dilakukan mediasi apalagi apabila sebelumnya sudah ada pria idaman lain, maka dengan adanya putusan pemidanaan akan mempermudah proses perceraian.

4) Para pihak tidak mentaati terhadap putusan mediasi, misalnya terdakwa mengulangi tindak kekerasan.

5) Ketidakpercayaan masyarakat terhadap aparat penegak hukum, terlihat ketika aparat penegak hukum menjadi mediator maka masyarakat memiliki persepsi negatif sehingga menimbulkan kecurigaan yang tidak beralasan.

Selama ini proses penyelesaian KDRT di Pekanbaru melalui mediasi penal cenderung masih cukup rendah sebagaimana data yang disajikan. Bahwa tercatat sejak tahun 2015-2017 ada 208 kasus KDRT yang ditangani oleh Satreskrim Polresta Pekanbaru. 
Hanya 57 kasus yang berhasil diselesaikan melalui mediasi penal sedangkan sisanya sebanyak 151 kasus harus di selesaikan melalui proses formal diikuti dengan permohonan perceraian. Artinya tingkat keberhasilan Polresta Pekanbaru dalam mengimplementasikan mediasi penal masih berada di bawah $50 \%$.

Hasil penelitian menunjukan bahwa rendahnya tingkat penyelesaian kasus KDRT terbentur oleh beberapa persoalan mendasar yang membuat perkara KDRT harus diselesaikan secara formal. Keadaan ini dinyatakan oleh penyidik Satreskrim Polresta Pekanbaru yang mengatakan bahwa mediasi penal menghadapi persoalan yang sangat mendasar.

Masalah operasional, kualitas penegak hukum dan kepatuhan pelaku ini menjadi kendala yang sangat mendasar untuk menyelesaikan perakara kekerasan dalam rumah tangga di Kota Pekanbaru dan menyulitkan penyidik untuk kembali merukunkan para pihak dalam keluarga yang utuh dan harmonis. Artinya dengan data yang ada dan berdasarkan hasil temuan penelitian dapat dikatakan bahwa penyelesaian kekerasan dalam rumah tangga melalui mediasi penal di Kota Pekanbaru masih belum mampu mencapai keadilan restoratif. Indikator belum tercapainya keadilan restoratif bisa dilihat dari angka/data kasus yang masuk kepada kepolisian persentase penyelesaian kasus lebih banyak diselesaikan secara formal (litigasipengadilan) diikuti dengan permohonan perceraian, padahal idealnya mediasi penal menghasilkan perdamaian yang memulihkan keretakan dalam rumah tangga.

Urgensi penerapan mediasi penal dalam kasus KDRT di Kota Pekanbaru secara filosofis bukan bertujuan untuk mengabolisi hukum pidana atau melebur hukum pidana dan hukum perdata. Restorative justice tetapi mengembalikan fungsi hukum pidana pada jalurnya yang semula yaitu ultimum remidium yaitu hukum pidana hanya dapat diberlakukan jika sarana hukum lain tidak dapat menyelesaikan kasus tersebut.285 Persoalan penyelesaian kasus kekerasan dalam rumah tangga dengan mediasi penal di Kota Pekanbaru belum memberikan harapan tercapainya keadilan restoratif yaitu keadilan yang mampu memberikan pemulihan situasi, kondisi dan keadaan keluarga yang retak seperti semula Tingginya angka pengajuan kasus kekerasan dalam rumah tangga di pengadilan diikuti pula dengan pengajuan perceraian di pengadilan agama dan negeri mayoritas isteri yang menjadi korban tidak mau lagi melanjutkan kehidupan rumah tangga dengan suami yang telah menganiaya. Alasannya cukup variatif mulai dari trauma setelah menjadi korban, ketidakpercayaan korban atas penyesalan pelaku, dampak kekerasan bagi kehidupan korban dan lain-lain.

Alasan-alasan ini menjadi dasar bagi korban dan keluarganya tidak mau mengikuti rekomendasi dari penyidik untuk melakukan mediasi atau kalaupun mediasi dilaksanakan memakan waktu lama karena sulitnya mendudukan kedua belah pihak dalam satu ruangan yang sama karena kebencian dan sakit hati yang mendalam dari korban dan keluarganya. Meskipun mediasi penal dapat dilaksanakan mayoritas korban tidak mau berdamai dengan pelaku karena ada kekhawatiran dalam diri korban jika ia berdamai dan rujuk kembali pelaku akan mengulangi perbuatannya.

Korban lebih memilih mengakhiri perkawinannya dengan pelaku dan mencari pasangan lain yang lebih baik dan menjamin kesejahteraan serta 
menyayangi dirinya daripada harus mengambil risiko rujuk kembali dengan pelaku yang sewaktu-waktu bisa mengulangi kekerasan terhadap dirinya. Kekhawatiran-kekhawatiran tersebut cukup berdasar untuk menjadi pertimbangan penegak hukum melanjutkan kasus ke pengadilan untuk melindungi keselamatan jiwa korban.

Kondisi ini secara praktik menyulitkan penegak hukum untuk merealisasikan mediasi penal yang menghasilkan keadilan restoratif karena problematika yang dialami pihak korban cukup memprihatinka. Masalah yang tidak bisa dipandang ringan adalah adanya ruang pelaku untuk mengulangi kekerasan jika terjadi kesepakatan damai akan mengancam jiwa dan fisik korban yang sudah memaafkannya. Dalam praktik di Kota Pekanbaru dan beberapa kota besar kerapkali terjadi pengulangan kekerasan pelaku terhadap korban setelah mereka saling memaafkan satu sama lain.

Persoalan rumah tangga yang cukup pelik dan pengaruh pergaulan sosial suami atau isteri menjadi faktor yang mendorong terjadi percekcokan dan berujung pada pengulangan kekerasan yang mungkin lebih membahayakan dari sebelumnya karena pelaku terbawa emosi yang berlebihan dan tidak bisa mengontrol jiwanya. Kondisi ini memberikan pengaruh terhadap proses mediasi penal dalam praktik. Dengan demikian mediasi penal kasus kekerasan rumah tangga sangat dipengaruhi kondisi-kondisi, keadaankeadaan yang meliputi kehidupan rumah tangga para pihak. Semakin kompleks persoalan rumah tangganya semakin sulit keadilan restoratif dicapai dalam mediasi penal sebaliknya semakin simple masalah rumah tangga dalam kasus kekerasan rumah tangga kemungkinan mediasi penal mencapai keadilan restoratif semakin terbuka.
Gambaran persoalan penyelesaian kekerasan dalam rumah tangga di atas dapat membutuhkan manajemen kasus yang handal dari aparat penegak hukum. Kompetensi, keahlian penegak hukum diuji saat dihadapkan pada kasus kekerasan yang cukup kompleks. Penegak hukum yang baik bukanlah penegak hukum yang menyerahkan sepenuhnya penyelesaian kasus secara mekanistik pada sistem peradilan pidana yang berujung pada penghukuman pelaku tanpa melihat dampaknya terhadap kerukunan rumah tangga.

ondisi ini bisa terwujud di Kota Pekanbaru apabila teori yang dikemukakan oleh Soerjono Soekanto sebagaimana diungkapkan di atas diimplementasikan pada proses mediasi penal kasus kekerasan dalam rumah tangga karena dalam teori tersebut menuntut adanya 5 (lima) faktor yang saling menentukan satu sama lain. Khusus bagi penegak hukum (penyidik) berperan cukup dominan dan menentukan apakah kasus kekerasan dalam rumah tangga berhasil di mediasi atau lanjut ke pengadilan.

Keadilan restoratif yang terwujud dalam upaya penyelesaian kekerasan dalam rumah tangga akan menyatukan kembali keharmonisan keluarga yang sempat retak disebabkan adanya unsur kekerasan karena esensi dari restoratif adalah megembalikan/ memuihkan/ mereparasi keadaan rumah tangga pelaku dan korban seperti semula sebelum terjadinya kekerasan. Keadilan ini pada akhirnya membawa kebahagiaan, keadilan dan kesejahteraan bagi keluarga yang sebelumnya terancam berpisah.

Secara empiris ditemukan berbagai dampak negatif yang terjadi di Kota Pekanbaru ketika kekerasan dalam rumah tangga gagal ditangani secara mediasi penal yaitu : 
a. Adanya penumpukan kasus di tingkat pengadilan yang tidak mungkin mengakomodir kepentingan para pihak sehingga dilihat dari segi filosofinya tidak memberikan manfaat bagi kedua belah pihak.

b. Penyelesaian kekerasan dalam rumah tangga cenderung diikuti dengan pengajuan perceraian di Pengadilan Agama sehingga menyebabkan angka perceraian meningkat.

c. Anak menjadi korban perceraian orang tuanya yang berpisah, seorang anak yang membutuhkan kasih sayang dalam masa tumbuh kembangnya harus menyaksikan perpisahan orang tua dan mengalami guncangan kejiwaan yang mempengaruhi psikologi anak dan broken home.

d. Dalam kehidupan rumah tangga di Indonesia pada umumnya terjadi penyatuan harta kekayaan. Pasal 35 ayat (1) Undang-Undang No. 1 Tahun 1974 tentang Perkawinan menentukan bahwa "harta benda yang diperoleh selama perkawinan menjadi harta bersama". Perkara pidana kekerasan yang diselesaikan di pengadilan membawa dampak terjadinya perebutan harta gonogini yang diperoleh selama perkawinan

\section{Akibat Hukum Atas Kesepakatan Damai Mediasi Penal Perkara Kekerasan Dalam Rumah Tangga (KDRT) di Kota Pekanbaru}

Hasil dari penelitian penulis didapat bahwa pada saat ini dalam penyelesaian perkara KDRT secara damai di Kota Pekanbaru telah dilakukan tersangka dengan korban melalui mediasi aparat kepolisian tetapi masih terjadi pengulangan tindak pidana kekerasan karena lemahnya pengawasan terhadap pelaksanaan hasil mediasi. Secara positivistik mediasi penal tidak dipandang tidak memiliki dasar hukum yang cukup kuat karena tidak diatur dalam undang-undang. Oleh karena itu, sebagian ahli hukum pidana mengatakan bahwa keputusan penyidik yang tidak mengajukan perkara ke pengadilan secara tegas melanggar asas legalitas yang menghendaki setiap perkara pidana harus diajukan ke pengadilan dan dipandang bahwa fenomena penghentian perkara pidana KDRT dengan alasan perdamaian bertentangan dengan asas oportunitas. Oleh karena yang berhak mengenyampingkan perkara hanyalah Jaksa Agung sebagaimana yang tertera pada Pasal 35 UU. No. 16 Tahun 2004 Tentang Kejaksaan, Lembaran Negara Republik Indonesia Tahun 2004 Nomor 67 yang menegaskan bahwa: "Jaksa Agung dapat mengesampingkan perkara demi kepentingan umum.

Sesungguhnya bila ditinjau dari segi legalistik positivistik pendapat tersebut di atas ada benarnya. Namun demikian, demi memenuhi tuntutan rasa keadilan masyarakat, hendaknya pengertian kepentingan umum dalam asas oputunitas tidak hanya ditekankan pada aspek kepentingan negara semata, melainkan harus pula meliputi aspekaspek kepentingan umum yang lainnya. Sebagaimana yang dikemukakan oleh Van Bemmelen bahwa kepentingan umum dalam kaitannya dengan penyampingan perkara adalah demi kepentingan negara, masyarakat dan pribadi. Dengan dasar itulah penulis berpendapat bahwa penyelesaian tindak pidana melalui musyawarah secara filosofis dapat dibenarkan dengan alas an sebagai berikut:

1. Perdamaian untuk menyelesaikan suatu perkara pidana sejauh perkara tersebut belum diajukan kemuka pengadilan, merupakan suatu hal yang regular terjadi, oleh karenanya dapatlah hal ini disebut sebagai 
regularity 2. Sikap tindak ajek (regularity) ini, merupakan pemantulan dari budaya hukum (legal culture) yang hidup dalam masyarakat

2. Perdamaian disini dapatlah diartikan sebagai suatu hubungan yang serasi (harmonis) antara mereka yang bersangkutan, yang berorientasi pada keadilan dan kebenaran

Bila dikaji dari perspektif asas, norma dan teori, mediasi penal disebutkan antara "ada" dan "tiada". Dikatakan "ada" oleh karena ternyata praktik mediasi penal dalam perkara KDRT di Kota Pekanbaru telah dilakukan oleh para penegak hukum dan para pihak beserta keluarganya serta penyelesaiannya dilakukan diluar pengadilan seperti melalui mekanisme musyawarah kekeluargaan.

Dikatakan "tiada" dikarenakan mediasi penal dalam perkara KDRT dalam ketentuan undang - undang tidak dikenal dan belum diatur dalam Sistem Peradilan Pidana akan tetapi dalam tataran di bawah undang-undang dikenal secara terbatas melalui diskresi penegak hukum, terbatas dan sifatnya parsial. Pada tataran di bawah undang undang penyelesaian perkara di luar pengadilan melalui mediasi penal diatur dalam Surat Kapolri No Pol: B/3022/XII/2009/SDEOPS tanggal 14 Desember 2009 tentang Penanganan Kasus Melalui Alternatif Dispute Resolution (ADR) serta Peraturan Kepala Kepolisian Negara Republik Indonesia Nomor 7 Tahun 2008 tentang Pedoman Dasar Strategi dan Implementasi Pemolisian Masyarakat Dalam Penyelenggaraan Tugas Polri dan secara konrkit diatur dalam Surat Edaran No 8/VII/2018 tentang Penerapan Keadilan Restoratif Dalam Perkara Pidana.

Sebuah fakta bahwa korban atau keluarga korban kekerasan dalam rumah tangga di Kota Pekanbaru yang telah melaporkan perkaranya kepada aparat penyidik lebih sering memilih untuk menyelesaikan perkaranya secara kekeluargaan dengan tidak melanjutkan proses penyelesaian kasusnya menurut jalur hukum pidana. Pilihan cara penyelesaian perkara oleh korban tersebut dilakukan dengan mencabut laporan yang telah dibuatnya sikap korban yang memilih untuk tidak meneruskan proses penyidikan atas kasus KDRT yang menimpanya selalu lebih banyak dibandingkan dengan sikap untuk membiarkan proses penyidikan atas kasus KDRT berjalan terus.

Pilihan cara penyelesaian kekerasan dalam rumah tangga dengan perdamaian di antara pelaku dan korban tersebut juga tampak dari temuan penelitian lapangan yang dilakukan oleh Bambang Soetono di Sumatera Barat dan Nusa Tenggara Barat tentang cara penyelesaian secara kekeluargaan untuk kasus-kasus kekerasan dalam rumah tangga.

Adanya temuantemuan mengenai perdamaian sebagai cara penyelesaian kasus kekerasan dalam rumah tangga di beberapa daerah tersebut menjadikan argumentasi untuk diakomodasinya pemikiran keadilan restoratif dalam kebijakan penanggulangan kekerasan dalam rumah tangga dengan menggunakan hukum pidana semakin menemukan landasannya.

Harmonisasi kepentingan pelaku, korban, dan masyarakat yang menjadi tujuan penyelesaian konflik menurut pemikiran keadilan restoratif tersebut sesuai dengan salah satu tujuan dari penghapusan kekerasan dalam rumah tangga. Dalam kaitannya dengan penyelesaian kasus tindak pidana kekerasan dalam rumah tangga melalui restorative justice (kekeluargaan), maka restorative justice adalah suatu 
penyelesaian perkara pidana dengan menggunakan pendekatan yang lebih menitikberatkan pada kondisi terciptanya keadilan dan keseimbangan bagi pelaku tindak pidana serta korbannya sendiri. Mekanisme tata acara dan peradilan pidana yang berfokus pada pemidanaan diubah menjadi proses dialog dan mediasi untuk menciptakan kesepakatan atas penyelesaian perkara pidana yang lebih adil dan seimbang bagi pihak korban dan pelaku. Restorative justice meliputi pemulihan hubungan antara pihak korban dan pelaku. Pemulihan hubungan ini bisa didasarkan atas kesepakatan bersama antara korban dan pelaku. Pihak korban dapat menyampaikan mengenai kerugian yang dide ritanya dan pelaku pun diberi kesempatan untuk menebusnya, melalui mekanisme ganti rugi, perdamaian, kerja sosial, maupun kesepakatan kesepakatan lainnya.

Persoalan yang mengemuka dalam praktek penyidikan tindak pidana KDRT adalah masalah akibat hukum yang terjadi apabila mediasi penal yang dilakukan penegak hukum dengan para pihak mencapai kesepakatan. Dalam berbagai kasus KDRT yang terjadi mempersoalkan bagaimana akibat hukum atas kesepakatan damai apakah bisa menghentikan penyidikan atau tidak.

Analisis mengenai akibat hukum mediasi penal dalam proses penyidikan tindak pidana KDRT bisa dimulai dari kewenangan polisi sebagai penyidik yang diatur dalam Pasal 16 Undang Undang Republik Indonesia No 2 Tahun 2002 tentang Kepolisian, yang menyebutkan bahwa dalam rangka menyelenggarakan tugas di bidang pidana, Kepolisian Negara Republik Indonesia, yaitu : a. melakukan penangkapan, penahanan, penggeledahan, dan penyitaan;

b. melarang setiap orang meninggalkan atau memasuki tempat kejadian perkara untuk kepentingan penyidikan;

c. membawa dan menghadapkan orang kepada penyidik dalam rangka penyidikan;

d. menyuruh berhenti orang yang dicurigai dan menanyakan serta memeriksa tanda pengenal diri; e. melakukan pemeriksaan dan penyitaan surat;

e. memanggil orang untuk didengar dan diperiksa sebagai tersangka atau saksi; g. mendatangkan orang ahli yang diperlukan dalam hubungannya dengan pemeriksaan perkar

f. mengadakan penghentian penyidikan;

g. menyerahkan berkas perkara kepada penuntut umum;

h. mengajukan permintaan secara langsung kepada pejabat imigrasi yang berwenang di tempat pemeriksaan imigrasi dalam keadaan mendesak atau mendadak untuk mencegah atau menangkal orang yang disangka melakukan tindak pidana;

i. memberi petunjuk dan bantuan penyidikan kepada penyidik pegawai negeri sipil serta menerima hasil penyidikan penyidik pegawai negeri sipil untuk diserahkan kepada penuntut umum; dan

j. mengadakan tindakan lain menurut hukum yang bertanggung jawab.

\section{KESIMPULAN}

a. Tindak pidana KDRT di Kota Pekanbaru secara faktual cenderung diselesaikan secara formal (litigasi) diikuti dengan permohonan perceraian mengingat upaya mediasi 
penal belum menunjukkan usaha dan hasil yang memadai karena secara empiris ditemukan beberapa persoalan mendasar, yaitu (a) masalah operasional (lemahnya komunikasi penegak hukum dengan para pihak, keterbatasan waktu, tindak lanjut hasil medasi) (b) kualitas (kompetensi) penegak hukum (c) masalah kepatuhan pelaku untuk menjalankan kesepakatan mediasi terbukti dengan adanya pengulangan tindak kekerasan kepada korban. Persoalan ini menyebabkan medialebih banyak mengalami kegagalan dan mendorong tingginya angka penyelesaian KDRT di pengadilan diikuti permohonan perceraian yang diajukan korban. Dengan demikian mediasi penal kekerasan rumah tangga belum mampu mewujudkan keadilan restoratif yang menuntut adanya tanggung jawab berupa perbaikan/reparasi untuk tujuan menjaga keutuhan dan keharmonisan serta mencegah perpecahan rumah tangga.

b. Kesepakatan perdamaian antara pelaku dengan korban dan keluarganya sebagai hasil mediasi penal memberikan akibat hukum terhadap proses penegakan hukum berupa penghentian proses penyidikan tindak pidana KDRT yang sedang berjalan di Kota Pekanbaru karena akta perdamaian yang disepakati para pihak merupakan produk hukum yang memiliki kekuatan hukum mengikat untuk dihormati dan dijalankan para pihak agar memberikan kepastian hukum bagi status perkara di masa mendatang. Penghentian penyidikan merupakan kebijakan diskresi penegak hukum di Kota Pekanbaru dengan persyaratan apabila pelaku mengingkari kesepakatan damai dengan mengulangi tindak pidana kekerasan maka akan langsung diproses secara formal (pengadilan). Persyaratan ini bertujuan untuk memberikan upaya perlindungan terhadap keamanan dan keselamatan korban pasca perdamaian.

\section{DAFTAR PUSTAKA}

Harkristitui Harkrisnowo, Hukum Pidana dan Kekerasan Terhadap Perempuan, UI Jakarta, 2000

Herry Kandati, Penerapan Mediasi Penal Oleh Kepolisian dalam Menanggulangi Tindak Pidana Sebagai Perwujudan Restoratif Justice, Jurnal Ilmu Huku, Vol II No II, Desember 2013

Mansour Fakih, Perkosaan dan Kekerasan Perspektif Analisis Gender, PKBI, Yogyakarta, 1997. 